\title{
Toxicity in leaves of rice exposed to cadmium is due to hydrogen peroxide accumulation
}

\author{
Yi Ting Hsu • Ching Huei Kao
}

Received: 1 May 2007 / Accepted: 11 July 2007 / Published online: 7 August 2007

(C) Springer Science + Business Media B.V. 2007

\begin{abstract}
The production of $\mathrm{H}_{2} \mathrm{O}_{2}$ in detached rice leaves of Taichung Native 1 (TN1) caused by $\mathrm{CdCl}_{2}$ was investigated. $\mathrm{CdCl}_{2}$ treatment resulted in $\mathrm{H}_{2} \mathrm{O}_{2}$ production in detached rice leaves. Diphenyleneiodonium chloride (DPI) and imidazole (IMD), inhibitors of NADPH oxidase (NOX), prevented $\mathrm{CdCl}_{2}$-induced $\mathrm{H}_{2} \mathrm{O}_{2}$ production, suggesting that $\mathrm{NOX}$ is a $\mathrm{H}_{2} \mathrm{O}_{2}$ genearating enzyme in $\mathrm{CdCl}_{2}$-treated detached rice leaves. Phosphatidylinositol 3-kinase inhibitors wortmanin (WM) or LY294002 (LY) inhibited $\mathrm{CdCl}_{2}$ inducted $\mathrm{H}_{2} \mathrm{O}_{2}$ production in detached rice leaves. Exogenous $\mathrm{H}_{2} \mathrm{O}_{2}$ reversed the inhibitory effect of WM or LY, suggesting that phosphatidylinositol 3phosphate is required for Cd-induced $\mathrm{H}_{2} \mathrm{O}_{2}$ production in detached rice leaves. Nitric oxide donor sodium nitroprusside (SNP) was also effective in reducing $\mathrm{CdCl}_{2}$-inducing accumulation of $\mathrm{H}_{2} \mathrm{O}_{2}$ in detached rice leaves. $\mathrm{Cd}$ toxicity was judged by the decrease in chlorophyll content. The results indicated that DPI, IMD, WM, LY, and SNP were able to reduce $\mathrm{Cd}$-induced toxicity of detached rice leaves. Twelve-day-old TN1 and Tainung 67 (TNG67) rice seedlings were treated with or without $\mathrm{CdCl}_{2}$. In
\end{abstract}

Responsible Editor: Fangjie J. Zhao.

Y. T. Hsu • C. H. Kao $(\bowtie)$

Department of Agronomy, National Taiwan University,

Taipei, Taiwan, Republic of China

e-mail: kaoch@ntu.edu.tw terms of Cd toxicity (leaf chlorosis), it was observed that rice seedlings of cultivar $\mathrm{TN} 1$ are $\mathrm{Cd}$-sensitive and those of cultivar TNG67 are Cd-tolerant. On treatment with $\mathrm{CdCl}_{2}, \mathrm{H}_{2} \mathrm{O}_{2}$ accumulated in the leaves of TN1 seedlings but not in the leaves of TNG67. Prior exposure of TN1 seedlings to $45^{\circ} \mathrm{C}$ for $3 \mathrm{~h}$ resulted in a reduction of $\mathrm{H}_{2} \mathrm{O}_{2}$ accumulation, as well as $\mathrm{Cd}$ tolerance of TN1 seedlings treated with $\mathrm{CdCl}_{2}$. The results strongly suggest that $\mathrm{Cd}$ toxicity of detached leaves and leaves attached to rice seedlings are due to $\mathrm{H}_{2} \mathrm{O}_{2}$ accumulation.

Keywords Cadmium $\cdot$ Hydrogen peroxide .

NADPH oxidase $\cdot$ Oryza sativa $\cdot$ Phosphatidylinositol 3-kinase $\cdot$ Phosphatiylinositol 3-phosphate

$\begin{array}{ll}\text { Abbreviations } \\ \text { ASC } & \text { Ascorbate } \\ \text { DAB } & \text { 3,3-Diaminobenzidine } \\ \text { DMSO } & \text { Dimethyl sulfoxide } \\ \text { DPI } & \text { Diphenyleneiodonium chloride } \\ \text { HS } & \text { Heat shock } \\ \text { IMD } & \text { Imidazole } \\ \text { LY } & \text { 294002 } \\ \text { NO } & \text { Nitric oxide } \\ \text { NOX } & \text { NADPH oxidase (EC 1.6.99.6) } \\ \text { PI3K } & \text { Phosphatidylinositol 3-kinase } \\ \text { PI3P } & \text { Phosphatidylinostolinositol 3-phosphate } \\ \text { ROS } & \text { Reactive oxygen species } \\ \text { SNP } & \text { Sodium nitroprusside }\end{array}$


TN1 Taichung Native 1

TNG67 Tainung 67

WM Wortmannin

\section{Introduction}

Reactive oxygen species (ROS) have been characterized as the key factor on the responses of plants to both biotic and abiotic stress (Apel and Hirt 2004). Initially, ROS were only regarded as damaging to cells. More recently, ROS emerged as ubiquitous signaling molecules participating in the recognition of and the response to stress factors (Foyer and Noctor 2005).

Inside plant cells, ROS can be produced in chloroplasts, mitochondria, peroxisome, glyoxysomes, byproducts of metabolic processes such as photosynthesis and respiration (Apel and Hirt 2004). Several biochemical mechanisms have been proposed to explain ROS production. Apoplastic $\mathrm{H}_{2} \mathrm{O}_{2}$ production can be mediated by cell-wall peroxidase, germinlike oxalate oxidases or amine oxidases (Apel and Hirt 2004; Mittler et al. 2004). However, it has been suggested that a NADPH oxidase (NOX), analogous to that which generated superoxide during the respiratory burst in mammalian phygocytes, can serve the source of the ROS detected in plants upon successful pathogen recognition (Auh and Murphy 1995; Doke 1983; Low and Merida 1996; Murphy and Auh 1996), in abscisic acid-mediated stomatal closure (Pei et al. 2000), in auxin-regulated gravitropic response (Joo et al. 2005; Neill et al. 2002), and under abiotic stresses such as temperature, wounding and ozone (Dat et al. 1998; López-Delgado et al. 1998; Orozco-Cárdenas and Ryan 1999; Sharma et al. 1996).

Cadmium $(\mathrm{Cd})$, a heavy metal toxic to humans, animals, and plants, is a widespread pollutant with a long biological half-life (Wagner 1993). It has been demonstrated that $\mathrm{Cd}$ can promote the generation of $\mathrm{H}_{2} \mathrm{O}_{2}$ (Hsu and Kao 2004; Kuo and Kao 2004; Olmos et al. 2003; Piqueras et al. 1999; Romero-Puertas et al. 2004; Sandalio et al. 2001; Schützendübel et al. 2001; Shah et al. 2001). The involvement of NOX in Cd-induced $\mathrm{H}_{2} \mathrm{O}_{2}$ production has been suggested in tobacco cells (BY-2 line; Olmos et al. 2003), pea leaves (Romero-Puertas et al. 2004), and pea roots (Rodriguez-Serrano et al. 2006).

It has been shown that NOX is activated by binding phosphatidylinositol 3-phosphate (PI3P), a product of phosphatidylinositol 3-kinase (PI3K), to the PX domain of $\mathrm{p} 40^{\text {phox }}$ (Ellson et al. 2001). In plant cells, PI3P is also known to be required for abscisic acid (ABA)-induced $\mathrm{H}_{2} \mathrm{O}_{2}$ production in guard cells (Jung et al. 2002; Park et al. 2003) and in leaves (Hung and Kao 2004), methyl jasmonateinduced $\mathrm{H}_{2} \mathrm{O}_{2}$ production in leaves (Hung et al. 2006), and auxin-induced ROS production in roots (Joo et al. 2005).

We have previously shown that $\mathrm{CdCl}_{2}$ increases the content of $\mathrm{H}_{2} \mathrm{O}_{2}$ in detached leaves of rice cultivar Taichung Native 1 (TN1; Hsu and Kao 2004). In this article, we investigate the possibilities that NOX and PI3P, as found in animals cells and guard cells, activate $\mathrm{H}_{2} \mathrm{O}_{2}$ generation in $\mathrm{CdCl}_{2}$-treated detached leaves of TN1 by using NOX inhibitors such as diphenyleneiodonium chloride (DPI) and imidazole (IMD), and PI3K inhibitors wortmanin (WM) and LY294002 (LY). Previously, we demonstrated that rice seedlings of cultivar TNG67 (TNG67) are more tolerant to $\mathrm{Cd}$ than those of cultivar TN1 (Hsu and Kao 2003). Evidence has been provided to show that abscisic acid is involved in Cd tolerance of TNG67 rice seedlings (Hsu and Kao 2003). It appears that these two cultivars of rice seedlings with different tolerance to $\mathrm{Cd}$ provide a good system to study mechanism of $\mathrm{Cd}$ toxicity of rice plants. Thus, using detached rice leaves of TN1 and intact leaves attached to rice seedlings of TN1 and TNG67, the possible link of $\mathrm{H}_{2} \mathrm{O}_{2}$ between $\mathrm{Cd}$ and subsequent toxicity (chlorophyll loss or leaf chlorosis) was also investigated.

\section{Materials and methods}

Plant material and treatments

Rice (Oryza sativa L., cv. TN1, or TNG67) seeds were sterilized with $2.5 \%$ sodium hypochlorite for $15 \mathrm{~min}$ and washed extensively with distilled water. These seeds were then germinated in Petri dishes with wetted filter paper at $37^{\circ} \mathrm{C}$ under dark conditions. After $48 \mathrm{~h}$ incubation, uniformly germinated seeds were selected and cultivated in a $500 \mathrm{ml}$ beaker containing half-strength Kimura B solution as described previously (Hsu and Kao 2003). The hydroponically cultivated seedlings were grown for 12 days in a Phytotron (Agricultural Experimental station, National Taiwan University, Taipei, Taiwan) with 
natural sunlight at $30^{\circ} \mathrm{C}$ (day) $/ 25^{\circ} \mathrm{C}$ (night) and $90 \%$ relative humidity. In our laboratory, detached leaves excised from the third leaf of TN1 rice seedlings have long been used as a model system for the studies of stress physiology. Thus, in experiments using detached rice leaves, the apical $3 \mathrm{~cm}$ of the third leaves of 12-day-old TN1 rice seedlings was used. A group of 10 segments was floated in a Petri dish containing $10 \mathrm{ml}$ of test solution. Incubation was carried out at $27^{\circ} \mathrm{C}$ in the light $\left(40 \mu \mathrm{mol} \mathrm{m} \mathrm{m}^{-2} \mathrm{~s}^{-1}\right)$. Test solutions included $\mathrm{CdCl}_{2}(5 \mathrm{mM}), \mathrm{H}_{2} \mathrm{O}_{2}(1 \mathrm{mM})$, IMD $(50 \mu \mathrm{M})$, nitric oxide (NO) donor, sodium nitroprusside (SNP, $100 \mu \mathrm{M}$ ), and PI3K inhibitors, LY $(100 \mu \mathrm{M})$ and WM $(1 \mu \mathrm{M})$. LY and WM stock solutions were prepared in $100 \%$ dimethyl sulfoxide (DMSO). For experiments of using leaves attached to TN1 and TNG67 seedlings, $\mathrm{CdCl}_{2}$ was added to halfstrength Kimura B solution at the time when the third leaf was fully expanded. $\mathrm{CdCl}_{2}$ concentrations at $0.5 \mathrm{mM}$ and $30 \mu \mathrm{M}$ were applied over a short (2 days) and a longer period ( 6 days), respectively. For some experiments, seedlings exposed to $30^{\circ} \mathrm{C}$ and $45^{\circ} \mathrm{C}$, respectively, for $3 \mathrm{~h}$ in darkness, to serve as non-heat shock (control) and heat shock (HS) treatments before the addition of $\mathrm{CdCl}_{2}(0.5 \mathrm{mM}$ or $30 \mu \mathrm{M})$.

\section{Evaluation of Cd toxicity}

For detached rice leaves, Cd toxicity was judged by the decease in chlorophyll content. Based on our experience from the experiments of $\mathrm{Cd}$ effect on rice seedlings, chlorosis is first observed in the second leaf of TN1 seedlings. Thus, Cd toxicity in the second leaves attached to rice seedlings caused by excess $\mathrm{Cd}$ was assessed by chlorosis.

Determination of chlorophyll and $\mathrm{H}_{2} \mathrm{O}_{2}$

Chlorophyll content was determined according to Wintermans and De Mots (1965) after extraction in $96 \%(\mathrm{v} / \mathrm{v})$ ethanol. $\mathrm{H}_{2} \mathrm{O}_{2}$ was visually detected in the leaves by using 3, 3-diaminobenzidine (DAB) as substrate (Orozco-Cárdenas and Ryan 1999). Cd- and inhibitor-treated detached rice leaves were first rinsed with distilled water and were then supplied through the cut ends with DAB $\left(1 \mathrm{mg} \mathrm{ml}^{-1}\right)$ solution for $24 \mathrm{~h}$ under light at $27^{\circ} \mathrm{C}$. Leaves were decolorized in boiling ethanol $(95 \%)$ for $0.5 \mathrm{~h}$. This treatment decolorized the leaves except for the brown polymer- ization spots produced by DAB with $\mathrm{H}_{2} \mathrm{O}_{2}$. After cooling, the leaves were extracted at room temperature with fresh ethanol to visualize the brown polymerization product produced by $\mathrm{DAB}$ with $\mathrm{H}_{2} \mathrm{O}_{2}$. To verify the specificity of brown spots, before staining with DAB some leaves were incubated for $2 \mathrm{~h}$ in $1 \mathrm{mM}$ ascorbate (ASC), a $\mathrm{H}_{2} \mathrm{O}_{2}$ scavenger. The $\mathrm{H}_{2} \mathrm{O}_{2}$ staining was repeated four times with similar results. The $\mathrm{H}_{2} \mathrm{O}_{2}$ content was also measured colorimetrically as described by Jana and Choudhuri (1982). $\mathrm{H}_{2} \mathrm{O}_{2}$ was extracted by homogenizing leaf tissue with phosphate buffer (50 mM, pH 6.5) containing $1 \mathrm{mM}$ hydroxylamine. The homogenate was centrifuged at $6,000 \mathrm{~g}$ for $25 \mathrm{~min}$. To determine $\mathrm{H}_{2} \mathrm{O}_{2}$ content, the extracted solution was mixed with $0.1 \%$ titanium chloride in $20 \%(\mathrm{v} / \mathrm{v}) \mathrm{H}_{2} \mathrm{SO}_{4}$. The mixture was then centrifuged at $6,000 \mathrm{~g}$ for $25 \mathrm{~min}$. The absorbance was measured at $410 \mathrm{~nm}$. Using this method, we found that absorbance increased linearly with the amount of $\mathrm{H}_{2} \mathrm{O}_{2}$ and addition of $\mathrm{H}_{2} \mathrm{O}_{2}$ to extracts resulted in the predicated increase of absorbance, i.e., added $\mathrm{H}_{2} \mathrm{O}_{2}$ was fully recovered (data not shown). The $\mathrm{H}_{2} \mathrm{O}_{2}$ content in leaf extracts was calculated using an extinction coefficient of $0.28 \mu \mathrm{mol}^{-1} \mathrm{~cm}^{-1}$.

Statistical analysis

Statistical differences between measurements $(n=4)$ on different treatments or on different times were analyzed following LSD test.

\section{Results}

$\mathrm{CdCl}_{2}$ increases $\mathrm{H}_{2} \mathrm{O}_{2}$ production and decreases chlorophyll in detached rice leaves

In the present study, $\mathrm{H}_{2} \mathrm{O}_{2}$ production was first visualized by a histochemical method with 3,3diaminobenzidine (DAB) that is based on the formation by $\mathrm{H}_{2} \mathrm{O}_{2}$ of brown polymerization product. The development of DAB- $\mathrm{H}_{2} \mathrm{O}_{2}$ reaction product in detached rice leaves could be prevented by $\mathrm{H}_{2} \mathrm{O}_{2}$ scavengers such as ASC, indicating that the DAB staining method for $\mathrm{H}_{2} \mathrm{O}_{2}$ is specific (Fig. 1a). $\mathrm{CdCl}_{2}$ treatment led to an accumulation of DAB- $\mathrm{H}_{2} \mathrm{O}_{2}$ reaction product (Fig. 1a). When $\mathrm{H}_{2} \mathrm{O}_{2}$ was measured colorimetrically, $\mathrm{CdCl}_{2}$ treatment also increased $\mathrm{H}_{2} \mathrm{O}_{2}$ 
Fig. 1 Effect of DPI, IMD, WM, LY, or SNP on the development of DAB- $\mathrm{H}_{2} \mathrm{O}_{2}$ reaction product (a), and the contents of $\mathrm{H}_{2} \mathrm{O}_{2}$ (b) and chlorophyll (c) in $\mathrm{CdCl}_{2}$ treated detached rice leaves (cv. TN1) in the presence or absence of $\mathrm{H}_{2} \mathrm{O}_{2}$. The concentrations of $\mathrm{CdCl}_{2}$, DPI, IMD, WM, LY, SNP, and ascorbate (ASC) were $5 \mathrm{mM}, 10 \mu \mathrm{M}, 50 \mu \mathrm{M}$, $1 \mu \mathrm{M}, 100 \mu \mathrm{M}, 100 \mu \mathrm{M}$, and $1 \mathrm{mM}$, respectively. DAB- $\mathrm{H}_{2} \mathrm{O}_{2}$ reaction product, for all treatments except ASC was visualized $24 \mathrm{~h}$ after treatment in the light. DAB- $\mathrm{H}_{2} \mathrm{O}_{2}$ reaction product for ASC treatment was visualized $2 \mathrm{~h}$ after treatment in the light. $\mathrm{H}_{2} \mathrm{O}_{2}$ and chlorophyll contents were measured $24 \mathrm{~h}$ after treatment in the light a

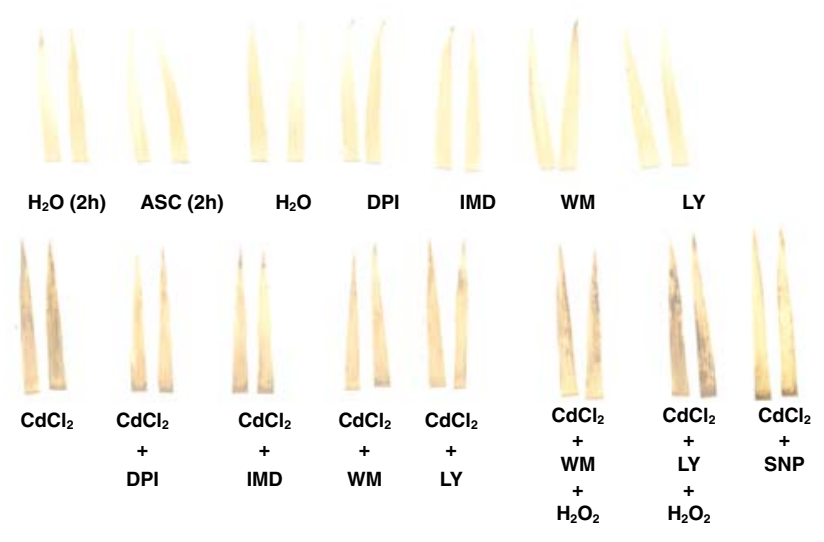

b
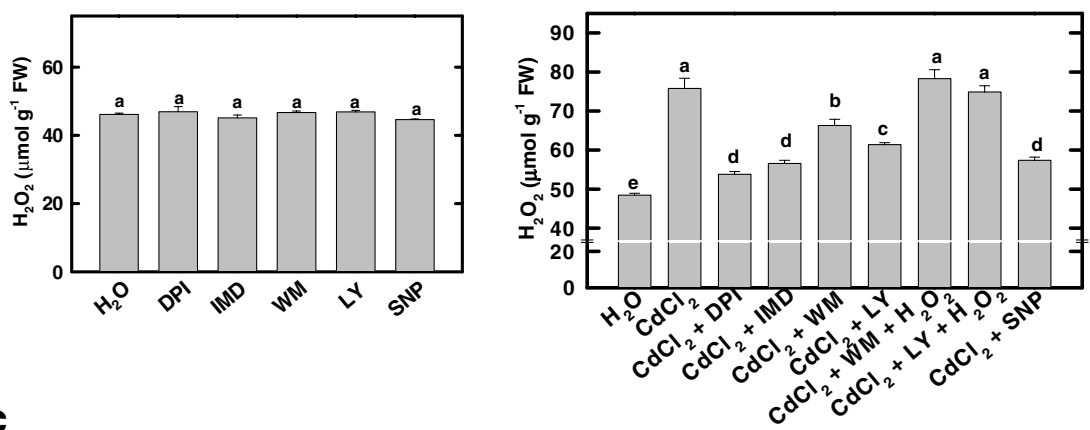

C

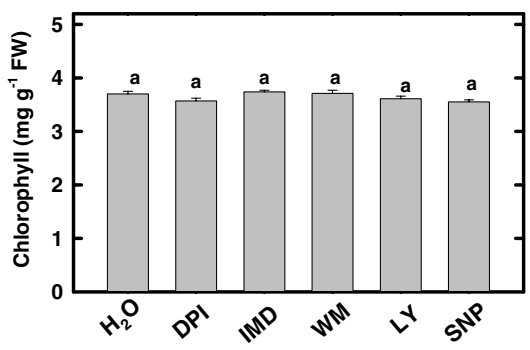

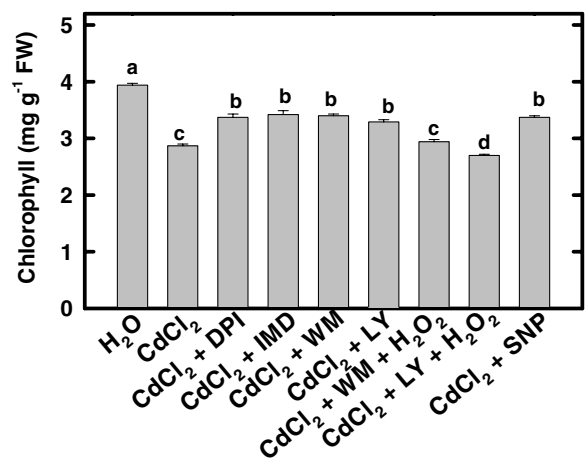

content in detached rice leaves (Fig. 1b). As expected, $\mathrm{CdCl}_{2}$ treatments resulted in a decrease in chlorophyll content (Fig. 1c).

The effect of NOX inhibitors

The role of $\mathrm{NOX}$ in the Cd-stimulated $\mathrm{H}_{2} \mathrm{O}_{2}$ production was investigated using NOX inhibitors such as diphenyleneiodonium chloride (DPI) and imidazole (IMD). When $1 \mu \mathrm{M}$ DPI or $100 \mu \mathrm{M}$ IMD was added to detached rice leaves simultaneously with $\mathrm{CdCl}_{2}$, a reduction of Cd-induced $\mathrm{H}_{2} \mathrm{O}_{2}$ accumulation was observed (Fig. 1a,b). The decrease in chlorophyll content in detached rice leaves by $\mathrm{CdCl}_{2}$ was reduced by DPI and IMD (Fig. 1c).

The effect of phosphatidylinositol 3-kinase inhibitors

It has been shown that PI3P is important in NOXmediated $\mathrm{H}_{2} \mathrm{O}_{2}$ production during ABA-induced 
stomatal closure (Jung et al. 2002), during ABApromoted leaf senescence (Hung and Kao 2005), during methyl jasmonate-induced leaf senescence (Hung et al. 2006) and during auxin-induced root gravitropic responses (Joo et al. 2005). Thus, it is of great interest to understand whether PI3P is also important in $\mathrm{CdCl}_{2}$-induced $\mathrm{H}_{2} \mathrm{O}_{2}$ production in rice leaves. Wortmannin (WM) and LY294002 (LY) are inhibitors of PI3K, a product of which is PI3P. When detached rice leaves were treated with a solution WM $(1 \mu \mathrm{M})$ or LY $(100 \mu \mathrm{M}), \mathrm{CdCl}_{2}$-induced accumulation of $\mathrm{H}_{2} \mathrm{O}_{2}$ in detached rice leaves was reduced (Fig. 1a,b). WM or LY also reduced Cd-induced decrease in chlorophyll content (Fig. 1c). Exogenous $\mathrm{H}_{2} \mathrm{O}_{2}(1 \mathrm{mM})$ was observed to be able to reverse the inhibitory effect of WM or LY on $\mathrm{H}_{2} \mathrm{O}_{2}$ production and chlorophyll content (Fig. 1a-c).

The effect of nitric oxide donor sodium nitroprusside

Nitric oxide (NO) is a bioactive free radical implicated in a number of physiological functions, including intra-cellular mediation of some animal responses (Anbar 1995). In plants, NO is involved in many physiological responses, such as pathogen response, programmed cell death, growth, germination, root organogenesis, phytoalexin production, internal iron availability, and ABA-dependent stomatal closure (Lamattina et al. 2003; Neill et al. 2003). We have previously demonstrated that $\mathrm{Cd}$ toxicity in detached rice leaves is reduced by $\mathrm{NO}$ (Hsu and $\mathrm{Kao}$ 2004). If $\mathrm{H}_{2} \mathrm{O}_{2}$ is responsible for $\mathrm{Cd}$ toxicity in detached rice leaves, then $\mathrm{H}_{2} \mathrm{O}_{2}$ accumulation is expected to be reduced by $\mathrm{NO}$ donor sodium nitroprusside SNP. As indicated in Fig. 1a, $\mathrm{b}$, it is indeed the case. In the present study, we also show that the decrease in chlorophyll content in detached rice leaves caused by $\mathrm{Cd}$ was reduced by SNP (Fig. 1c).

$\mathrm{CdCl}_{2}$ induces $\mathrm{H}_{2} \mathrm{O}_{2}$ accumulation in the leaves of cultivar TN1 seedlings but not in cultivar TNG67

Figure 2 shows the effect of $0.5 \mathrm{mM} \mathrm{CdCl}_{2}$ on the chlorosis of the second leaves of rice seedlings. It is clear that $\mathrm{CdCl}_{2}$ treatment resulted in Cd toxicity of the second leaves of TN1, but not in TNG67 seedlings (Fig. 2) at 2 days after $\mathrm{Cd}$ treatment. If $\mathrm{H}_{2} \mathrm{O}_{2}$ is important in regulating $\mathrm{Cd}$ toxicity, then

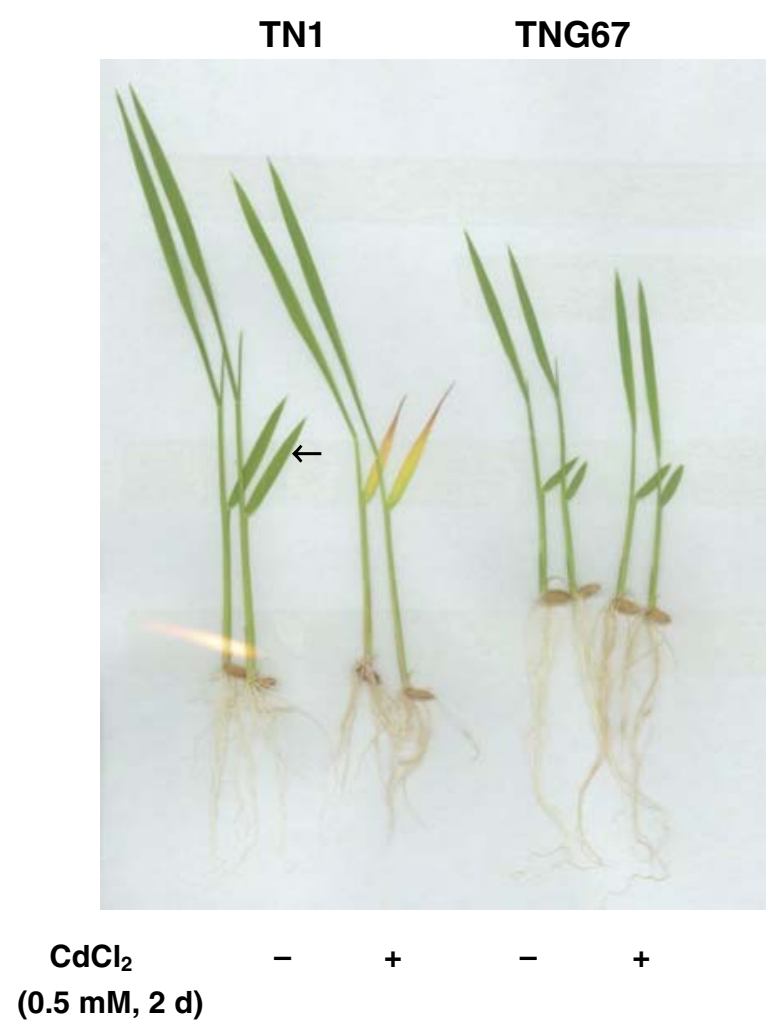

Fig. 2 Effect of $\mathrm{CdCl}_{2}(0.5 \mathrm{mM})$ on the toxicity (chlorosis) in the second leaves of TN1 and TNG67 rice seedlings. Rice seedlings were cultivated in half-strength Kimura B solution in a Phytotron with natural sunlight at $30^{\circ} \mathrm{C}$ (day) $/ 25^{\circ} \mathrm{C}$ (night) and $90 \%$ relative humidity. $\mathrm{CdCl}_{2}(0.5 \mathrm{mM})$ was added to halfstrength Kimura B solution at the time when the third leaves of both TN1 and TNG67 seedlings were fully expanded. Pictures were taken 2 days after the addition of $\mathrm{CdCl}_{2}(0.5 \mathrm{mM})$. Arrow indicates the second leaves

$\mathrm{H}_{2} \mathrm{O}_{2}-$ DAB reaction product and $\mathrm{H}_{2} \mathrm{O}_{2}$ content are expected to be more and higher, respectively, in $\mathrm{CdCl}_{2}$-treated TN1 seedlings than in TNG67. As indicated in Fig. 3, it is indeed the case.

The concentration of $\mathrm{CdCl}_{2}$ used in the aforementioned study was $0.5 \mathrm{mM}$. We also conducted experiments with lower $\mathrm{CdCl}_{2}$ concentration, $30 \mu \mathrm{M}$, applied over a longer period (6 days). Cd toxicity and $\mathrm{H}_{2} \mathrm{O}_{2}$ generation was also observed to be more pronounced in TN1 seedlings than TNG67 treated with lower concentration $(30 \mu \mathrm{M}) \mathrm{CdCl}_{2}$ for 6 days (Figs. 4 and 5). Thus, the responses to lower $\mathrm{CdCl}_{2}$ concentration are basically in accordance with those to higher $\mathrm{CdCl}_{2}$ concentration. 
Prior high temperature exposure of TN1 seedlings reduces $\mathrm{Cd}$-induced $\mathrm{H} 2 \mathrm{O} 2$ accumulation

Exposure in the range of $2 \mathrm{~min}$ to a few hours at temperature $5^{\circ} \mathrm{C}$ to $15^{\circ} \mathrm{C}$ above the normal growing temperature is usually called HS treatment. Prior exposure to HS has been shown to increase the tolerance of plants to subsequent $\mathrm{Cd}$ stress (Chen and
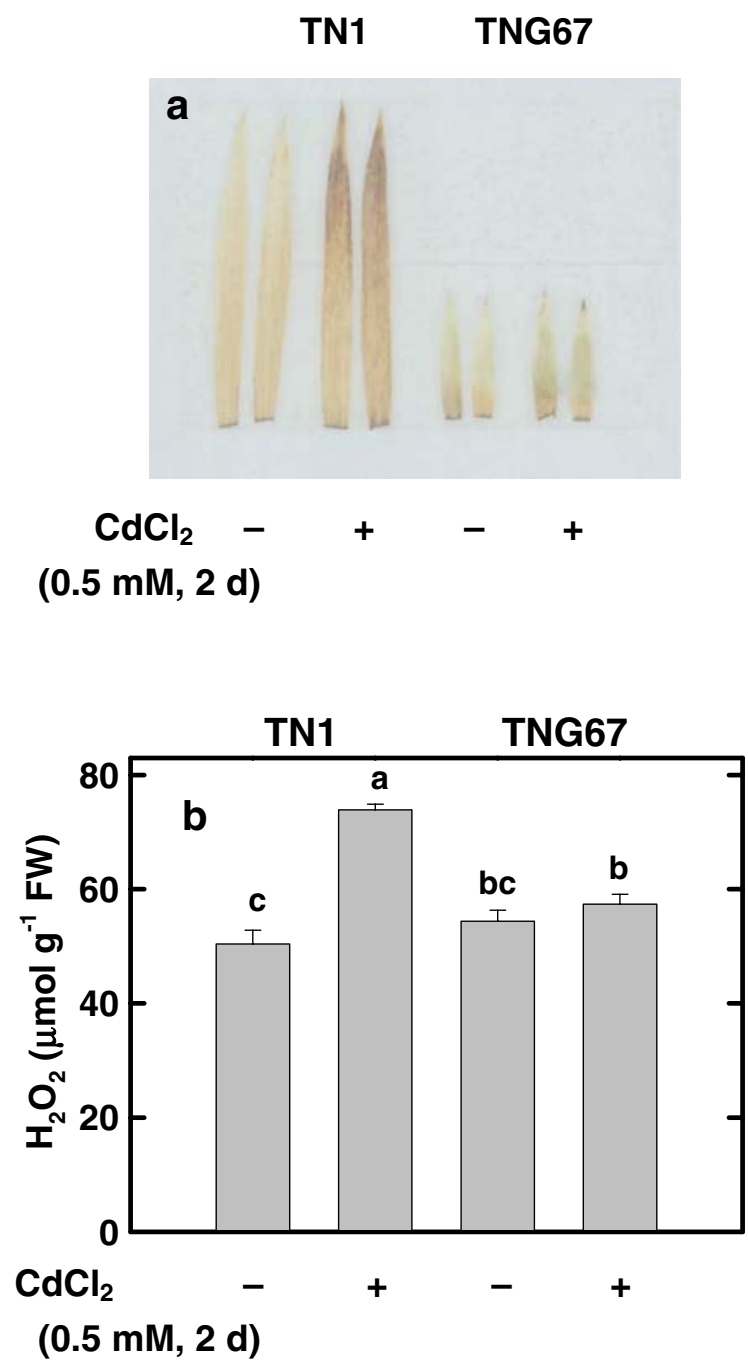

Fig. 3 Effect of $\mathrm{CdCl}_{2}(0.5 \mathrm{mM})$ on $\mathrm{DAB}-\mathrm{H}_{2} \mathrm{O}_{2}$ reaction product (a) and $\mathrm{H}_{2} \mathrm{O}_{2}$ content (b) in the second leaves of TN1 and TNG67 rice seedlings. Rice seedlings were cultivated in half-strength Kimura B solution in a Phytron with natural sunlight at $30^{\circ} \mathrm{C}$ (day) $/ 25^{\circ} \mathrm{C}$ (night) and $90 \%$ relative humidity. $\mathrm{CdCl}_{2}(0.5 \mathrm{mM})$ was added to half-strength Kimura B solution at the time when the third leaves of both TN1 and TNG67 seedlings were fully expanded. The second leaves were excised to visualize $\mathrm{H}_{2} \mathrm{O}_{2}-\mathrm{DAB}$ reaction product and measure $\mathrm{H}_{2} \mathrm{O}_{2}$ content 2 days after the addition of $\mathrm{CdCl}_{2}(0.5 \mathrm{mM})$
TN1

TNG67

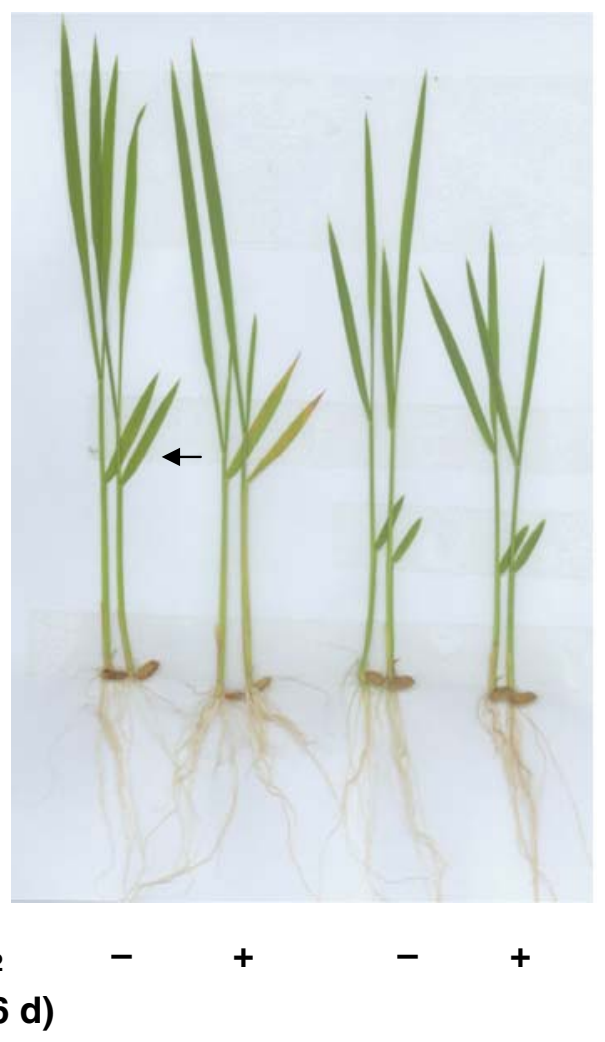

Fig. 4 Effect of $\mathrm{CdCl}_{2}(30 \mu \mathrm{M})$ on the toxicity (chlorosis) in the second leaves of $\mathrm{TN} 1$ and TNG67 rice seedlings. Rice seedlings were cultivated in half-strength Kimura B solution in a Phytotron with natural sunlight at $30^{\circ} \mathrm{C}$ (day) $/ 25^{\circ} \mathrm{C}$ (night) and $90 \%$ relative humidity. $\mathrm{CdCl}_{2}(30 \mu \mathrm{M})$ was added to halfstrength Kimura B solution at the time when the third leaves of both TN1 and TNG67 seedlings were fully expanded. Pictures were taken 2 days after the addition of $\mathrm{CdCl}_{2}(30 \mu \mathrm{M})$. Arrow indicates the second leaves

Kao 1995; Orzech and Burke 1988). To test if prior high temperature exposure of TN1 seedlings affects subsequent $\mathrm{Cd}$ stress, TN1 seedlings were pretreated at $45^{\circ} \mathrm{C}$ for $3 \mathrm{~h}$. It was observed that HS pretreatment induces tolerance of $\mathrm{Cd}$ stress $(0.5 \mathrm{mM}$ or $30 \mu \mathrm{M})$ in TN1 seedlings (Figs. 6 and 8). Figures 7 and 9 also show that HS pretreatment resulted in the production of less $\mathrm{H}_{2} \mathrm{O}_{2}$ in the second leaves of TN1 seedlings treated with $\mathrm{CdCl}_{2}$ than that non-HS $\left(30^{\circ} \mathrm{C}\right)$ pretreatment.

\section{Discussion}

In the present study, $0.5 \mathrm{mM}$ or $30 \mu \mathrm{M} \mathrm{CdCl}$ was used to evaluate $\mathrm{Cd}$ toxicity of leaves attached to rice 
seedlings. In a recent study on 64 soils (urban, forest, and agricultural soils) containing various levels of $\mathrm{Cd}$ contamination, free dissolved $\mathrm{Cd}$ concentrations ranged from 0.1 to 2,000 nM (Sauvé et al. 2000). Thus. The $30 \mu \mathrm{M} \mathrm{CdCl} 2$ used in some of our experiments can be considered to be very high. Basically, rice seedlings in our study were considered to be suffering from acute $\mathrm{Cd}$ toxicity.

It has been shown that $\mathrm{Cd}$ is able to produce $\mathrm{H}_{2} \mathrm{O}_{2}$ (Hsu and Kao 2004; Kuo and Kao 2004; Olmos et al.

TN1

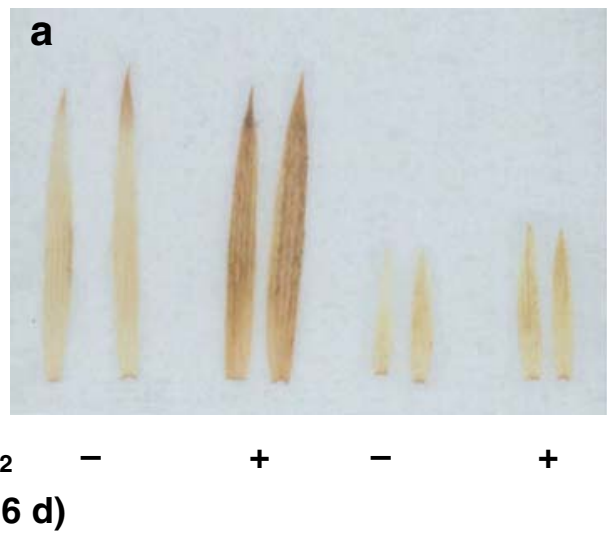

(30 $\mu \mathrm{M}, 6 \mathrm{~d})$

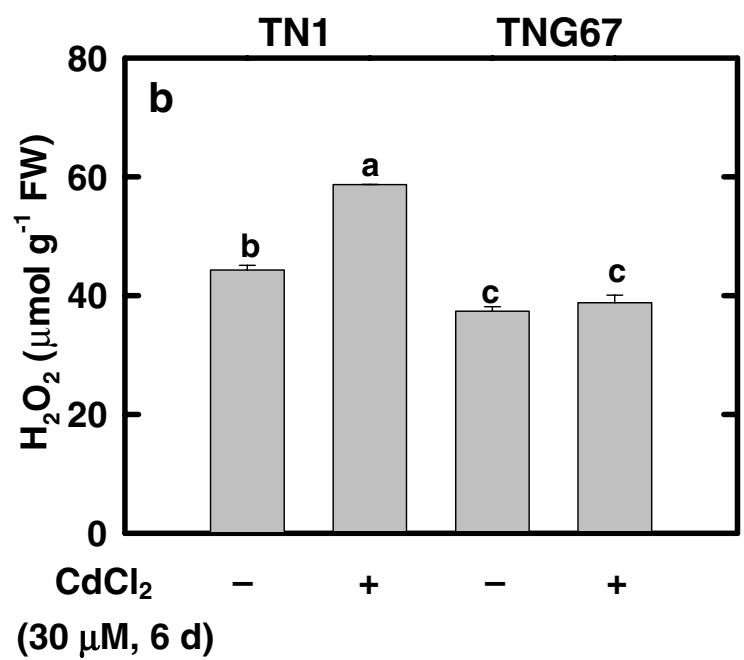

Fig. 5 Effect of $\mathrm{CdCl}_{2}(30 \mu \mathrm{M})$ on $\mathrm{DAB}-\mathrm{H}_{2} \mathrm{O}_{2}$ reaction product (a) and $\mathrm{H}_{2} \mathrm{O}_{2}$ content (b) in the second leaves of TN1 and TNG67 rice seedlings. Rice seedlings were cultivated in half-strength Kimura B solution in a Phytron with natural sunlight at $30^{\circ} \mathrm{C}$ (day) $/ 25^{\circ} \mathrm{C}$ (night) and $90 \%$ relative humidity. $\mathrm{CdCl}_{2}(30 \mu \mathrm{M})$ was added to half-strength Kimura B solution at the time when the third leaves of both TN1 and TNG67 seedlings were fully expanded. The second leaves were excised to visualize $\mathrm{H}_{2} \mathrm{O}_{2}-\mathrm{DAB}$ reaction product and measure $\mathrm{H}_{2} \mathrm{O}_{2}$ content 6 days after the addition of $\mathrm{CdCl}_{2}(30 \mu \mathrm{M})$

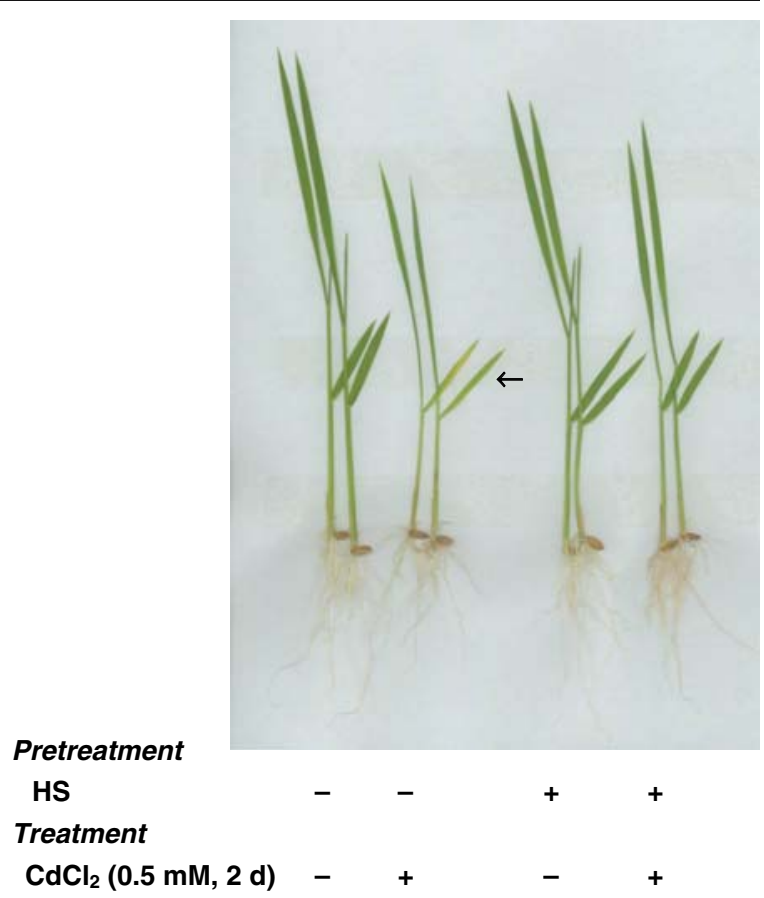

Fig. 6 Effect of HS pretreatment on the toxicity (chlorosis) in the second leaves of rice seedlings (cv. TN1) in the presence or absence of $\mathrm{CdCl}_{2}(0.5 \mathrm{mM})$. Rice seedlings at the time when the third leaves fully expanded were transferred to $30^{\circ} \mathrm{C}$ (non$\mathrm{HS}$ ) or $45^{\circ} \mathrm{C}$ (HS) in the dark for $3 \mathrm{~h}$. Rice seedlings were then cultivated in a Phytotron with natural sunlight at $30^{\circ} \mathrm{C}$ (day)/ $25^{\circ} \mathrm{C}$ (night) and $80 \%$ relative humidity. Pictures were taken 2 days after the addition of $\mathrm{CdCl}_{2}(0.5 \mathrm{mM})$ to half-strength Kimura B solution. Arrow indicated the second leaves

2003; Piqueras et al. 1999; Romero-Puertas et al. 2004; Sandalio et al. 2001; Schützendübel et al. 2001; Shah et al. 2001). Here, we also show that $\mathrm{CdCl}_{2}$ induced $\mathrm{H}_{2} \mathrm{O}_{2}$ production in detached rice leaves by histochemistry with DAB (Fig. 1a) and colorimetric methods (Fig. 1b). Wounding is known to induce $\mathrm{H}_{2} \mathrm{O}_{2}$ production (Orozco-Cárdenas and Ryan 1999). When detached rice leaves are used, wounding is always a problem. However in the present study, each long and narrow rice leaf was cut transversely; thus the area of wounding was very small. Therefore, $\mathrm{H}_{2} \mathrm{O}_{2}$ generation of detached rice leaves induced by $\mathrm{CdCl}_{2}$ is unlikely to be complicated the wounding effect.

A role for plasma membrane NOX in the production of the $\mathrm{H}_{2} \mathrm{O}_{2}$ has been a recent focus in ROS signaling (Sagi and Flurhr 2006). Here, we show that DPI and IMD, inhibitors of NOX, reduced $\mathrm{CdCl}_{2}$ induced $\mathrm{H}_{2} \mathrm{O}_{2}$ accumulation (Fig. 1a,b). It has been shown that a high concentration of DPI can affect 
other enzymes potentially involved in the production of ROS, including cell wall peroxidase and NO synthase (Bolwell et al. 1998). The fact that $\mathrm{CdCl}_{2}$-induced $\mathrm{H}_{2} \mathrm{O}_{2}$ accumulation in detached rice leaves can be inhibited by low concentration of DPI $(1 \mu \mathrm{M})$ and can be inhibited by both DPI and IMD (Fig. 1a,b) strongly suggest that $\mathrm{CdCl}_{2}$-dependent $\mathrm{H}_{2} \mathrm{O}_{2}$ production originated, at least in part, from plasma membrane NOX. The involvement of NOX in Cd-induced $\mathrm{H}_{2} \mathrm{O}_{2}$ production has also been suggested in tobacco cells (Olmos et al. 2003), pea leaves (Romero-Puertas et al. 2004), and pea roots (Rodriguez-Serrano et al. 2006).

It has been shown that zinc deficiency enhanced $\mathrm{NAD}(\mathrm{P}) \mathrm{H}$-dependent superoxide radical production in
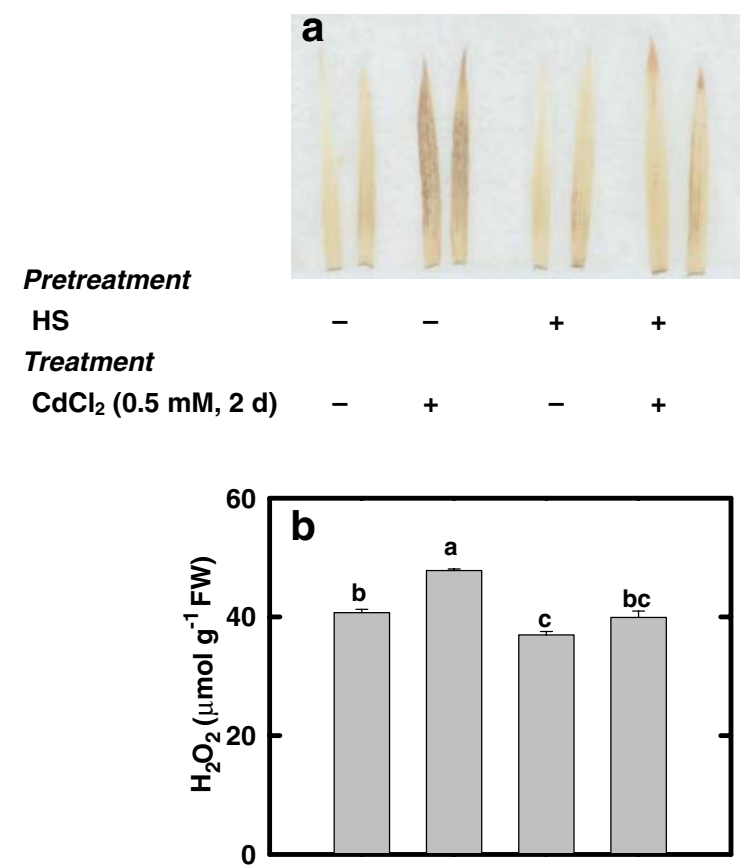

\section{Pretreatment}

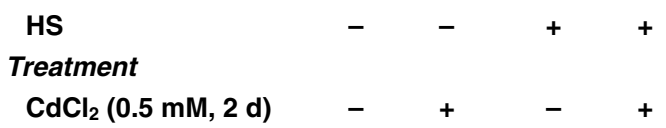

Fig. 7 Effect of $\mathrm{HS}$ pretreatment on the $\mathrm{H}_{2} \mathrm{O}_{2}-\mathrm{DAB}$ reaction product (a) and $\mathrm{H}_{2} \mathrm{O}_{2}$ content (b) in the second leaves of rice seedlings (cv. TN1) in the presence or absence of $\mathrm{CdCl}_{2}$ $(0.5 \mathrm{mM})$. Rice seedlings at the time when the third leaves fully expanded were transferred to $30^{\circ} \mathrm{C}$ (non-HS) or $45^{\circ} \mathrm{C}$ (HS) in the dark for $3 \mathrm{~h}$. Rice seedlings were then cultivated in a Phytotron with natural sunlight at $30^{\circ} \mathrm{C}$ (day) $/ 25^{\circ} \mathrm{C}$ (night) and $80 \%$ relative humidity. The second leaves were were excised to visualize $\mathrm{H}_{2} \mathrm{O}_{2}-$ DAB reaction product and measure $\mathrm{H}_{2} \mathrm{O}_{2}$ content, 2 days after the addition of $\mathrm{CdCl}_{2}(0.5 \mathrm{mM})$ to halfstrength Kimura B solution

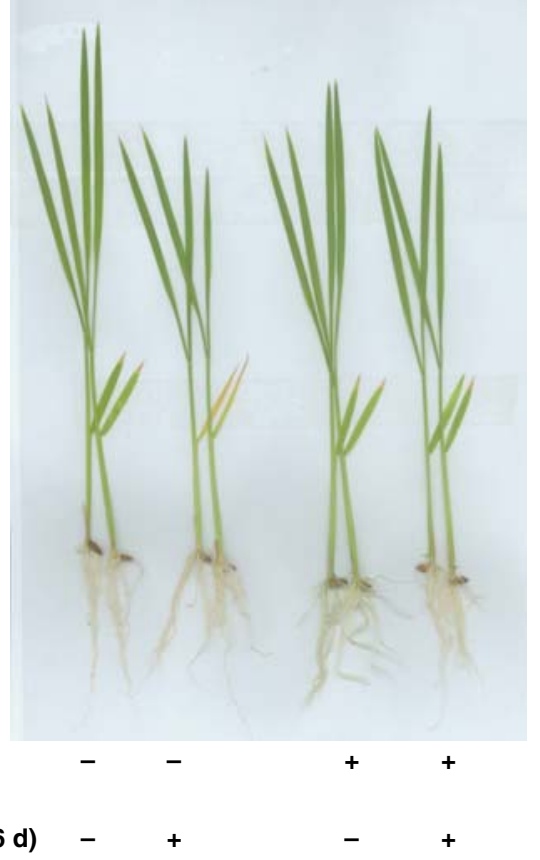

Pretreatment

HS

Treatment

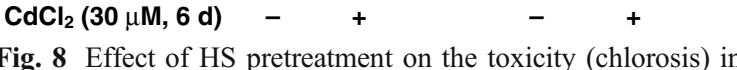
the second leaves of rice seedlings (cv. TN1) in the presence or absence of $\mathrm{CdCl}_{2}(30 \mu \mathrm{M})$. Rice seedlings at the time when the third leaves fully expanded were transferred to $30^{\circ} \mathrm{C}$ (non-HS) or $45^{\circ} \mathrm{C}$ (HS) in the dark for $3 \mathrm{~h}$. Rice seedlings were then cultivated in a Phytotron with natural sunlight at $30^{\circ} \mathrm{C}$ (day)/ $25^{\circ} \mathrm{C}$ (night) and $90 \%$ relative humidity. Pictures were taken 6 days after the addition of $\mathrm{CdCl}_{2}(30 \mu \mathrm{M})$ to half-strength Kimura B solution. Arrow indicated the second leaves

plasma membrane vesicles isolated from roots of bean plants (Pinton et al. 1994). Since cadmium toxicity has been shown to be associated zinc deficiency (Sandalio et al. 2001), thus the possibility that a Cdinduced reduction in $\mathrm{Zn}$ availability could stimulate superoxide radical production in leaves of rice seedlings cannot be excluded.

The mechanism of ROS production and the molecules involved have been well investigated in animal cells, particularly in neutrophils. The NOX, which consists of many components, is responsible for ROS production in neutrophil cells and is activated by the binding of PI3P to one of the components (Ellson et al. 2001). In plant cells, PI3P is also known to be required for ABA-induced $\mathrm{H}_{2} \mathrm{O}_{2}$ production in guard cells (Jung et al. 2002; Park et al. 2003) and in detached rice leaves (Hung and Kao 2005), methyl jasmonate-induced $\mathrm{H}_{2} \mathrm{O}_{2}$ production in detached rice leaves (Hung et al. 2006), and auxininduced ROS production in roots (Joo et al. 2005). It 
a
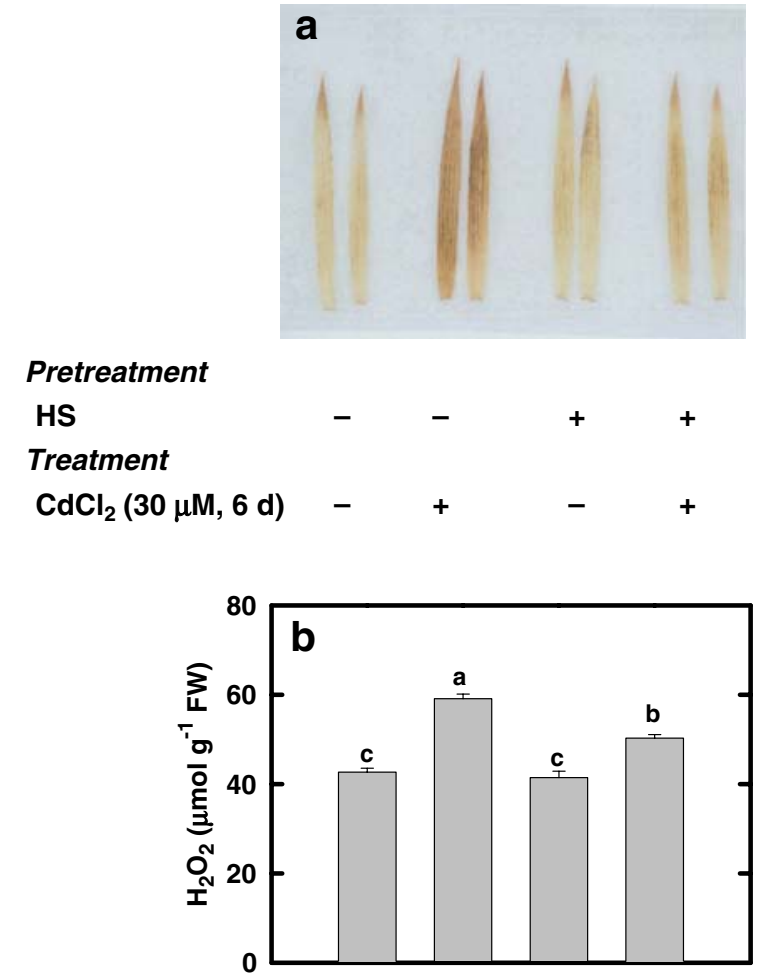

\section{Pretreatment}

HS

\section{Treatment}

$\mathrm{CdCl}_{2}(30 \mu \mathrm{M}, 6 \mathrm{~d})$

Fig. 9 Effect of $\mathrm{HS}$ pretreatment on the $\mathrm{H}_{2} \mathrm{O}_{2}-\mathrm{DAB}$ reaction product (a) and $\mathrm{H}_{2} \mathrm{O}_{2}$ content (b) in the second leaves of rice seedlings (cv. TN1) in the presence or absence of $\mathrm{CdCl}_{2}$ $(30 \mu \mathrm{M})$. Rice seedlings at the time when the third leaves fully expanded were transferred to $30^{\circ} \mathrm{C}$ (non-HS) or $45^{\circ} \mathrm{C}$ (HS) in the dark for $3 \mathrm{~h}$. Rice seedlings were then cultivated in a Phytotron with natural sunlight at $30^{\circ} \mathrm{C}$ (day) $/ 25^{\circ} \mathrm{C}$ (night) and $90 \%$ relative humidity. The second leaves were were excised to visualize $\mathrm{H}_{2} \mathrm{O}_{2}-\mathrm{DAB}$ reaction product and measure $\mathrm{H}_{2} \mathrm{O}_{2}$ content 6 days after the addition of $\mathrm{CdCl}_{2}(30 \mu \mathrm{M})$ to halfstrength Kimura B solution

appears that $\mathrm{PI} 3 \mathrm{P}$ is important in $\mathrm{CdCl}_{2}$-induced $\mathrm{H}_{2} \mathrm{O}_{2}$ production based on two lines of evidence. First, LY or WM, inhibitor of $\mathrm{PI} 3 \mathrm{~K}$, was able to reduce $\mathrm{CdCl}_{2}$ induced $\mathrm{H}_{2} \mathrm{O}_{2}$ production (Fig. 1a,b). Second, exogenous $\mathrm{H}_{2} \mathrm{O}_{2}$ reversed the inhibitory effect of the PI3K inhibitors on $\mathrm{CdCl}_{2}$-indcued $\mathrm{H}_{2} \mathrm{O}_{2}$ accumulation (Fig. 1a,b). These results supported further that NOX is involved in $\mathrm{CdCl}_{2}$-induced $\mathrm{H}_{2} \mathrm{O}_{2}$ production. In neutrophlis, $\mathrm{PI} 3 \mathrm{P}$ regulated $\mathrm{H}_{2} \mathrm{O}_{2}$ production by binding the non-catalytic component $\mathrm{p} 40^{\text {phox }}$ of the NOX (Ellson et al. 2001). However, a rice homolog of $\mathrm{p} 40^{\text {phox }}$ has not been reported. Therefore, the detailed mechanism of the action of PI3P during $\mathrm{H}_{2} \mathrm{O}_{2}$ production in the rice leaves needs further investigation.

The fact that NOX and PI3K inhibitors, which reduced the Cd-induced $\mathrm{H}_{2} \mathrm{O}_{2}$ production (Fig. 1a,b), were able to prevent $\mathrm{Cd}$-decreased chlorophyll content in detached rice leaves (Fig. 1c) suggests that $\mathrm{Cd}$ toxicity of detached rice leaves is due to $\mathrm{H}_{2} \mathrm{O}_{2}$ accumulation.

Several reports convincingly demonstrate that NO is a able to counteract the toxicity of paraquat and diquat, which are known to generate ROS in potato and rice leaves (Beligni and Lamattina 1999; Hung et al. 2002), and block $\mathrm{H}_{2} \mathrm{O}_{2}$ production induced by jasmonic acid in tomato leaves (Orozco-Cárdenas and Ryan 2002). Here we also showed that SNP, a NO donor, blocks $\mathrm{H}_{2} \mathrm{O}_{2}$ production and reduces $\mathrm{Cd}$ toxicity (Fig. 1a,b). It has been shown that polyamines are able to protect against oxidative damage caused by paraquat (Chang and Kao 1997), acid rain (Velikova et al. 2000) and heavy metals such as Cd and $\mathrm{Cu}$ (Groppa et al. 2001). Recently, we reported that polyamines (spermidine and spermine) are able to protect $\mathrm{Cd}$-induced toxicity of detached rice leaves and this protection is most likely related to the avoidance of $\mathrm{H}_{2} \mathrm{O}_{2}$ generation and $\mathrm{Cd}$ uptake (Hsu and Kao 2007). All these results support further that $\mathrm{Cd}$ toxicity is due to $\mathrm{H}_{2} \mathrm{O}_{2}$ production in detached rice leaves.In plants, the most general symptom of $\mathrm{Cd}$ toxicity is chlorosis (Das et al. 1997). Based on chlorosis and chlorophyll loss of the second leaves of rice seedlings, it was demonstrated that rice seedlings of cultivar TNG67 are more tolerant to Cd than those of cultivar TN1 (Hsu and Kao 2003; Kuo and Kao 2004). Evidence has also been provided to show that $\mathrm{Cd}$ content in the second leaf and roots of TNG67 seedlings remained unchanged and slightly increased, respectively, after Cd treatment (Hsu and Kao 2003; Kuo and Kao 2004). In contrast, a marked increase in $\mathrm{Cd}$ content in Cd-treated TN1 leaves and roots was observed (Hsu and Kao 2003; Kuo and Kao 2004). We also observed that higher content of Cd in TN1 than TNG67 leaves results in more production of $\mathrm{H}_{2} \mathrm{O}_{2}$ in TN1 than TNG67 leaves (Kuo and Kao 2004). The fact that on treatment with $\mathrm{CdCl}_{2}(0.5 \mathrm{mM}$ for 2 days or $30 \mu \mathrm{M}$ for 6 days), the $\mathrm{H}_{2} \mathrm{O}_{2}$ content increased in $\mathrm{Cd}$-sensitive TN1 seedlings but not in Cd-tolerant TNG67 (Figs. 3 and 5) supports the idea 
that $\mathrm{Cd}$ toxicity is due to $\mathrm{H}_{2} \mathrm{O}_{2}$ accumulation caused by $\mathrm{Cd}$. Prior exposure to $\mathrm{HS}$ has been shown to increase tolerance of plants to subsequent $\mathrm{Cd}$ stress (Chen and Kao 1995; Orzech and Burke 1988). Here we also demonstrated that HS pretreatment of TN1 seedlings resulted in the reduction of $\mathrm{H}_{2} \mathrm{O}_{2}$ production as well as Cd toxicity of TN1 seedlings treated with $\mathrm{CdCl}_{2}$ (Figs. 6, 7, 8, and 9). $\mathrm{H}_{2} \mathrm{O}_{2}$ production is believed to be the consequence of lower capacity of antioxidant system to avoid $\mathrm{H}_{2} \mathrm{O}_{2}$ accumulation. In this connection, HS pretreatment may increase the capacity of antioxidant system to reduce $\mathrm{H}_{2} \mathrm{O}_{2}$ production under the subsequent $\mathrm{Cd}$ treatment. Our unpublished data indeed show that HS pretreatment of rice seedlings resulted in higher contents of reduced glutathione and ascorbate and higher activities of glutathione reductase and ascorbate peroxidase than non-HS.

Based on the results obtained from detached rice leaves and intact leaves attached to rice seedlings, we conclude that $\mathrm{Cd}$ toxicity in leaves of rice seedlings is due to $\mathrm{H}_{2} \mathrm{O}_{2}$ accumulation. This conclusion is basically consistent with the results of Cho and Seo (2005), who reported that a lower $\mathrm{H}_{2} \mathrm{O}_{2}$ accumulation confers Cd-tolerance in Arabidopsis seedlings.

Acknowledgements This work was supported by a research grant from the National Science Council of the Republic of China (NSC 94-2313-B-002-028).

\section{References}

Anbar M (1995) Nitric oxide: a synchronizing chemical messenger. Experientia 51:545-550

Apel K, Hirt H (2004) Reactive oxygen species: metabolism, oxidative stress, and signal transduction. Annu Rev Plant Biol 55:373-399

Auh C-K, Murphy TM (1995) Plasma membrane redox enzyme is involved in the synthesis of $\mathrm{O}_{2}^{-}$and $\mathrm{H}_{2} \mathrm{O}_{2}$ by Phytophthora elicitor-stimulated rose cells. Plant Physiol 107:1241-1247

Beligni MV, Lamattina L (1999) Nitric oxide protects against cellular damage produced by methyl viologen herbicides in potato plants. Nitric Oxide 3:199-208

Bolwell GP, Davies DR, Gerrish C, Auh CK, Murphy TM (1998) Comparative biochemistry of the oxidative burst produced by rose and French bean cells reveals two distinct mechanisms. Plant Physiol 116:1374-1385

Chang CJ, Kao CH (1997) Paraquat toxicity is reduced by polyamines in rice leaves. Plant Growth Regul 22:163-168

Chen SL, Kao CH (1995) Prior temperature exposure affects subsequent $\mathrm{Cd}$-induced ethylene production in rice leaves. Plant Sci 104:135-138
Cho U-H, Seo N-H (2005) Oxidative stress in Arabidopsis thaliana exposed to cadmium is due to hydrogen peroxide accumulation. Plant Sci 168:113-120

Das P, Sammantaray S, Rout GR (1997) Studies on cadmium toxicity: a review. Environ Pollut 98:29-36

Dat JF, Foyer CH, Scott IM (1998) Changes in salicylic acid and antioxidants during induced thermotolerance in mustard seedlings. Plant Physiol 118:1455-1461

Doke N (1983) Generation of superoxide anion by potato tuber protoplasts during the hypersensitive response to hyphal cell wall components of Phytophthora infestans and specific inhibition of the reaction by suppressors of hypersensitivity. Physiol Plant Pathol 23:359-367

Ellson CD, Gobert-Gosse S, Anderson KE, Davidson K, Erdjument-Bromage H, Tempst P, Thring JW, Cooper MA, Lim Z-Y, Holmes AB, Gaffney PRJ, Coadwell J, Chilvers ER, Hawkins PT, Steppheas LR (2001) PtdIns(3) $\mathrm{P}$ regulated the neutrophil oxidase complex by binding to the PX domain of $\mathrm{p} 40^{\text {phox }}$. Nat Cell Biol 3:679-682

Foyer CH, Noctor G (2005) Oxidant and antioxidant signaling in plants: a re-evaluation of the concept of oxidative stress in a physiological context. Plant Cell Environ 28: 1056-1071

Groppa MD, Tomaro ML, Benavides MP (2001) Polyamines as protectors against cadmium or copper-induced oxidative damage in sunflower leaf discs. Plant Sci 161:481-488

Hsu YT, Kao CH (2003) Role of abscisic acid in cadmium tolerance of rice (Oryza sativa L.) seedlings. Plant Cell Environ 20:867-874

Hsu YT, Kao CH (2004) Cadmium toxicity is reduced by nitric oxide in rice leaves. Plant Growth Regul 42:227-238

Hsu YT, Kao CH (2007) Cadmium-induced oxidative damage in rice leaves is reduced by polyamines. Plant Soil 291:27-37

Hung KT, Kao CH (2004) Phosphatidylinositol 3-phosphate is required for abscisic acid-induced hydrogen peroxide production in rice leaves. Plant Growth Regul 45:96-101

Hung KT, Kao CH (2005) Nitric oxide counteracts the senescence of rice leaves induced by hydrogen peroxide. Bot Bull Acad Sin 46:21-28

Hung KT, Chang CJ, Kao CH (2002) Paraquat toxicity is reduced by nitric oxide in rice leaves. J Plant Physiol 159:159-166

Hung KT, Hsu YT, Kao CH (2006) Hydrogen peroxide is involved in methyl jasmonate-induced senescence of rice leaves. Physiol Plant 127:293-303

Jana S, Choudhuri MH (1982) Glycolate metabolism of these submerged aquatic angiosperms during aging. Aquat Bot 12:345-354

Joo JH, Yoo HJ, Hwang I, Lee JS, Nam KH, Bae YS (2005) Auxin-induced reactive oxygen species production required the activation of phosphatidyliniaitol 3-kinase. FEBS Lett 579:1243-1248

Jung J-Y, Kim Y-W, Kwak JM, Hwang J-U, Young J, Schroeder JI, Hwang I, Lea Y (2002) Phosphatidyl-inostol 3- and 4-phosphate are required for normal stomatal movements. Plant Cell 147:2397-2412

Kuo MC, Kao CH (2004) Antioxidant enzyme activities are upregulated in response to cadmium in sensitive, but not in tolerant rice (Oryza sativa L.) seedlings. Bot Bull Acad Sin 45:291-299 
Lamattina L, Garaia Mata C, Graziano M, Pagnussat G (2003) Nitric oxide: the versatility of an extensive signal molecule. Annu Rev Plant Biol 54:109-136

López-Delgado H, Dat JF, Foyer CH, Scoot IM (1998) Induction of tolerance in potato microplants by acetylsalicylic acid and $\mathrm{H}_{2} \mathrm{O}_{2}$. J Exp Bot 49:713-720

Low PS, Merida JR (1996) The oxidative burst in plant defense: function and signal transduction. Physiol Plant 96:533-542

Mittler R, Vanderauwera S, Gollery M, Van Breusegem F (2004) Tends Plant Sci 9:490-498

Murphy TM, Auh C-K (1996) The superoxide synthases of plasma membrane preparations from cultured rose cells. Plant Physiol 110:621-629

Neill SJ, Desikan R, Hancock J (2002) Hydrogen peroxide signaling. Curr Opin Plant Biol 5:388-395

Neill SJ, Desikan R, Hancock JT (2003) Nitric oxide signalings in plants. New Phytol 159:11-35

Olmos EO, Martínez-Solano JR, Piqueras A, Hellín E (2003) Early steps in the oxidative burst induced by cadmium in cultured tobacco cells (BY-2 line). J Exp Bot 54:291-301

Orozco-Cárdenas ML, Ryan CA (1999) Hydrogen peroxide is generated systemically in plant leaves by wounding and systemin via the octadecanoid pathway. Proc Natl Acad Sci USA 96:6553-6557

Orozco-Cárdenas ML, Ryan CA (2002) Nitric oxide negatively modulate wound signaling in tomato plants. Plant Physiol 130:487-493

Orzech KA, Burke JJ (1988) Heat shock and the protection against metal toxicity in wheat leaves. Plant Cell Environ 11:711-714

Park K-Y, Jung J-Y, Park J, Hwang JU, Kim Y-W, Hwang I, Lee Y (2003) A role for phosphatidylinositol 3-phosphate in abscisic acid-induced reactive oxygen species generation in guard cells. Plant Physiol 132:92-98

Pei Z-M, Murata Y, Benning G, Thomine S, Klüsener B, Allen GJ, Grill E, Schroeder JI (2000) Calcium channels activiated by hydrogen peroxide mediate abscisic acid signaling in guard cells. Nature 406:731-734

Pinton R, Cakmak I, Marschner H (1994) Zinc deficiency enhanced NAD(P)H-dependent superoxide radical production in plasma membrane vesicles isolated from roots of bean plants. J Exp Bot 45:45-50

Piqueras A, Olmos E, Martińez-Solano JR, Hellín E (1999) Cdinduced oxidative burst in tobacco BY2 cells: time course, subcellular location and antioxidant response. Free Radic Res 31:S33-S38

Rodriguez-Serrano M, Romero-Puertas C, Zabalza A, Corpas FJ, Gómez M, del Rio LA, Sandalio LM (2006) Cadmium effect on oxidative metabolism of pea (Pisum sativum L.) roots. Imaging of reactive oxygen species and nitric oxide accumulation in vivo. Plant Cell Environ 291:1532-1544

Romero-Puertas MC, Rodriguez-Serrano M, Corpas FJ, Gómez M, del Rio LA, Sandalio LM (2004) Cadmiuminduced subcellular accumulation of $\mathrm{O}_{2}^{-}$and $\mathrm{H}_{2} \mathrm{O}_{2}$ in pea leaves. Plant Cell Environ 27:1122-1134

Sagi M, Flurhr R (2006) Production of reactive oxygen species by plant NADPH oxidase. Plant Physiol 141:336-340

Sandalio LM, Dalurzo HC, Gómez M, Romero-Puertas MC, del Rio LA (2001) Cadmium-induced changes in the growth and oxidative metabolism of pea plant. J Exp Bot 52:2115-2126

Sauvé S, Norvell WA, McBride M, Hendershot W (2000) Speciation and complexation of cadmium in extracted soil solutions. Environ Sci Technol 34:291-296

Schützendübel A, Schwang $\mathrm{P}$, Teichmann T, Gross K, Langenfeld-Heyer R, Godbold DL, Polle A (2001) Cadmium-induced changes in antioxidative systems, hydrogen peroxide content, and differentiation in scots pine roots. Plant Physiol 127:887-898

Shah K, Kumar RG, Verma S, Dubey RS (2001) Effect of cadmium on lipid peroxidation, superoxide anion generation and activities of antioxidant enzymes in growing rice seedlings. Plant Sci 161:1135-1144

Sharma Y, León J, Roskinn I, Davies KR (1996) Ozoneinduced responses in Arabidopsis thaliana: the role of salicylic acid in the accumulation of defense-related transcripts and induced resistance. Proc Natl Acad Sci USA 93:5099-5104

Velikova V, Yordanov I, Edreva S (2000) Oxidative stress and some antioxidant systems in acid rain-treated bean plants. Protective role of exogenous polyamines. Plant Sci 151:59-66

Wagner GJ (1993) Accumulation of cadmium in crop plants and its consequences to human health. Adv Agron 5:173212

Wintermans JFGM, De Mots A (1965) Spectrophotometric characteristics of chlorophyll $\mathrm{a}$ and $\mathrm{b}$ and their pheophytins in ethanol. Biochim Biophys Acta 109:448-453 